\title{
"Nice Questions" Unanswered: Grokster, Sony's Staple Article of Commerce Doctrine, and the Deferred Verdict on Internet File Sharing
}

\author{
David G. Post, Annemarie Bridy, \\ and Timothy Sandefur*
}

"From the advent of the player piano, every new means of reproducing sound has struck a dissonant chord with musical copyright owners, often resulting in federal litigation."

MGM Studios Inc. v. Grokster, Ltd., 380 F.3d 1154, 1158 (9th Cir. 2004).

"In some cases where an ordinary article of commerce is sold, nice questions may arise as to the point at which the seller becomes an accomplice in a subsequent illegal use by the buyer."

Kalem Co. v. Harper Brothers, 222 U.S. 55, 62 (1911) (Holmes, J.) (emphasis added).

\section{Introduction}

When is the developer or distributor of a copying technology legally responsible for the copyright infringements committed by users of that technology? Over the past twenty years or so, development and deployment of digital copying technologies (personal computers, CD and DVD burners, iPods and other portable music devices, the Internet itself, etc.), and tools for Internet file sharing and file distribution, have thrust that question into the center of a

${ }^{*}$ David G. Post is I. Herman Stern Professor of Law at Temple University Law School; Annemarie Bridy is a law clerk to the Hon. Dolores K. Sloviter of the U.S. Court of Appeals for the Third Circuit; and Timothy Sandefur is the lead attorney in the Economic Liberty Project at the Pacific Legal Foundation. 
high-profile public debate. That debate gave rise to the most closely watched copyright case of recent years, MGM Studios Inc. v. Grokster, Ltd. ${ }^{1}$ The Ninth Circuit Court of Appeals had held that defendants Grokster and StreamCast, the developers and distributors of peerto-peer file-sharing software, were shielded from copyright liability by the so-called "Sony doctrine" derived from the Supreme Court's landmark 1984 case of Sony Corporation of America v. Universal City Studios, Inc. ${ }^{2}$ (also called the "Betamax" case). The Ninth Circuit interpreted that doctrine to mean that distributors of copying technology that is "capable of commercially significant noninfringing use" $^{\prime \prime}$ are shielded from liability for the infringement committed by users of the technology, unless the distributors had "specific knowledge of infringement" obtained "at a time at which they contributed to the infringement" and had "failed to act upon that information."

The Supreme Court unanimously reversed, holding that because Grokster and StreamCast had distributed their software "with the object of promoting its use to infringe copyright," as shown by "clear expression or other affirmative steps taken to foster infringement," Sony did not protect them from liability, whether or not their software was "capable of commercially significant noninfringing use."4

The unanimous decision in the copyright holders' favor is, obviously, a big loss for Grokster Inc. and StreamCast, Ltd.; its broader implications for Internet file-sharing practices and file-sharing technology, however, are much less clear. To understand what those implications might be, we have to rewind, as the Supreme Court did, to Sony.

\section{Rewind: The Betamax Case}

When Sony introduced its Betamax ${ }^{\mathrm{TM}}$ videotape recorder into the U.S. market in $1975,{ }^{5}$ there were, of course, no personal computers, or home photocopiers, or TiVOs, or MP3 files, or home networksand, needless to say, no Internet. The VCR, for the first time, enabled

${ }^{1} 125$ S. Ct. 2764 (2005).

${ }^{2} 464$ U.S. 417 (1984).

${ }^{3}$ MGM Studios Inc. v. Grokster, Ltd., 380 F.3d 1154, 1160, 1162 (9th Cir. 2004) (internal quotation marks and alterations omitted).

${ }^{4}$ Grokster, 125 S. Ct. at 2780 (emphasis added).

${ }^{5}$ The history of the VCR is long and complicated. The first home video recorders were reel-to-reel devices sold in the 1960s. The first cassette recorder was marketed by Philips in the 1970s. Debra A. Sitzberger, Copyright Law-Who Gets The Picture?, 57 Wash. L. Rev. 599, 608 n.74 (1982). 
television viewers to record, easily and conveniently and for relatively low cost, television broadcasts right off the air and to play them back at a later time. ${ }^{6}$

The entertainment industries, generally speaking, were not pleased. "We are facing," Jack Valenti, then-president of the Motion Picture Association of America, told Congress,

a very new and a very troubling assault on our fiscal security, on our very economic life and we are facing it from a thing called the video cassette recorder and its necessary companion called the blank tape. And it is like a great tidal wave just off the shore. This video cassette recorder and the blank tape threaten profoundly the life-sustaining protection, I guess you would call it, on which copyright owners depend, on which film people depend, on which television people depend and it is called copyright. ${ }^{7}$

The VCR, he famously continued, "is to the American film producer and the American public as the Boston strangler is to the woman home alone." ${ }^{\prime 8}$

In 1976, in response to this new and purportedly deadly threat, Universal Studios and Walt Disney Productions filed suit, in the Central District of California, asserting, among other things, that Sony was liable for copyright infringement. ${ }^{9}$ As a remedy, plaintiffs sought (a) an injunction against the continued manufacture and distribution of the VCR, (b) money damages to compensate for past

${ }^{6}$ And not a great deal else; in those early (i.e., pre-Blockbuster) days, pre-recorded videotapes were largely unavailable (except at adult bookstores), so the purchasers of VTRs (as they were known then) were, presumably, interested primarily in using their new gizmos for off-the-air taping.

${ }^{7}$ Home Recording of Copyrighted Work: Hearings on H.R. 4783, H.R. 4794, H.R. 4808, H.R. 5488, and H.R. 5705 Before the Subcommittee on Courts, Civil Liberties, and the Administration of Justice of the House Committee on the Judiciary, 97th Cong., 2d Sess., Serial No. 97, Part I, 4-8 (1982) (statement of Jack Valenti), available at http://cryptome.org/hrcw-hear.htm (visited July 18, 2005) (hereinafter VCR Hearings).

${ }^{8} I d$. at 8 .

${ }^{9}$ Universal City Studios, Inc. v. Sony Corp. of America, 480 F. Supp. 429, 432 (C.D. Cal. 1979). The defendants in the original action were Sony, the manufacturer of the Betamax; four retailers (Carter Hawley Hale Stores, Robinson's, Bullock's, and Henry's Camera Corp.), and a sole consumer (William Griffiths). Later, the advertising agency of Doyle Dane Bernback, Inc. was added to the list of defendants. Id. at 432. 
infringement(s), and (c) a share (to be determined by the district court) of Sony's profits from the sale of the VCR. ${ }^{10}$

The precise contours of the copyright claim were noteworthy. Ordinarily, to prove that a defendant is infringing its copyright, a plaintiff has to prove three things:

(a) that the work(s) in question (here, the previously broadcast television shows and movies) are protected by copyright; ${ }^{11}$

(b) that he/she owns one (or more) of the exclusive rights that comprise the copyright-e.g., the exclusive right to "reproduce the copyrighted work in copies,"12 to "distribute copies ... of the copyrighted work to the public,"13 or to "display the copyrighted work publicly"; $;$ and

(c) that the defendant, without authorization to do so, took some action that violated one or more of those exclusive rights. ${ }^{15}$

Elements (a) and (b) were straightforward; no one disputed that plaintiffs' television shows and movies were protected by copyright or that plaintiffs owned the relevant copyrights. Element (c) was trickier, however; what had Sony done that could constitute a violation of any of plaintiffs' exclusive rights in their copyrighted works? Sony had not, itself, come anywhere near plaintiffs' copyrighted works; it's not as though it had hard-wired the preceding six months of All in the Family or Bonanza into each Betamax it sold. If anyone were taking action that violated one or more of plaintiffs' exclusive copyright rights, it was, of course, Betamax users, not Sony; Sony wasn't "reproducing" or "distributing" or "displaying" movies or

\footnotetext{
${ }^{10}$ Section 504 of the Copyright Act provides that, in an action for infringement, the copyright owner "is entitled to recover the actual damages suffered by him or her as a result of the infringement, and any profits of the infringer that are attributable to the infringement and [that] are not taken into account in computing the actual damages." 17 U.S.C. § 504(b) (emphasis added).

${ }^{11}$ Under the Copyright Act, all "works of authorship fixed in any tangible medium of expression" are protected by copyright as of the moment of their creation. 17 U.S.C. § 102(a) (2005).

${ }^{12} 17$ U.S.C. § 106(1).

${ }^{13} 17$ U.S.C. § 106(3).

${ }^{14} 17$ U.S.C. $\S 106(5)$.

${ }^{15} 17$ U.S.C. § 501(a) ("Anyone who violates any of the exclusive rights of the copyright owner ... is an infringer of the copyright or right of the author, as the case may be.").
} 
television shows. It was stamping out circuit boards and transistors and switches, putting assembled machines into boxes, and shipping the boxes to retailers.

The studios, therefore, could not (and did not) claim that Sony was a "direct infringer" of their copyrights. Instead, their claim was that, by manufacturing and selling a device that made it so easy for purchasers to infringe their copyrights, ${ }^{16}$ Sony had committed a kind of indirect, or third-party, infringement.

There was precedent in copyright law for holding third parties liable for the infringements of others, in certain circumstances; in fact, two theories of third-party copyright liability, so-called "vicarious" and "contributory" copyright infringement, had been recognized by courts beginning in the early part of the twentieth century. Each was a relatively straightforward outgrowth of traditional common law tort principles under which liability can be imposed on one person for the tortious acts of another. "Vicarious" copyright liability evolved from the doctrine of respondeat superior, which extends tort liability to persons in control of the wrongdoer (typically employees or agents). Under this doctrine, anyone with the "right and ability to control" a copyright infringer, and "a direct financial interest" ${ }^{\prime \prime 17}$ in the infringer's actions, is jointly and severally liable with the infringer for those infringements. ${ }^{18}$ "Contributory" liability, for its part, derives from the equally venerable doctrine of "aiding and abetting" in tort. Just as you can be liable if you induce or encourage someone else to commit acts that you know (or should know) constitute a tort, so, too, can you be liable for encouraging

\footnotetext{
${ }^{16}$ See VCR Hearings, supra note 7, at 5 (Valenti claiming the VCR had a "single mission: ... to copy copyrighted material that belongs to other people"), available at http://cryptome.org/hrcw-hear.htm.

${ }^{17}$ Universal City Studios, Inc. v. Sony Corp. of America, 480 F. Supp. 429, 461 (C.D. Cal. 1979) (quoting Gershwin Publishing Corp. v. Columbia Artists Management, Inc., 443 F.2d 1159, 1162 (2d Cir. 1971)).

${ }^{18}$ MGM Studios Inc. v. Grokster, Ltd., 380 F.3d 1154, 1164 (9th Cir. 2004). The doctrine of vicarious liability in copyright law goes back at least as far as the famous "Dance-Hall Cases" in which the proprietors of dance halls and similar establishments were held to be vicariously liable for the infringements of the dance bands in their employ. See, e.g., Dreamland Ball Room, Inc. v. Shapiro, Bernstein \& Co., 36 F.2d 354, 355 (7th Cir. 1929). See also Famous Music Corp. v. Bay State Harness Horse Racing and Breeding Association, Inc., 554 F.2d 1213, 1214-15 (1st Cir. 1977); Gershwin Publishing, 443 F.2d at 1161-62; KECA Music, Inc. v. Dingus McGee's Co., 432 F. Supp. 72, 74-75 (W.D. Mo. 1977).
} 
copyright infringement: one who "with knowledge of the infringing activity, induces, causes or materially contributes to the infringing conduct of another, may be held liable as a 'contributory' infringer."19

Liability under one or another of these doctrines had been imposed, for example, on a department store that had leased space in its store to someone selling infringing recordings, ${ }^{20}$ on the proprietors of dance halls, and similar establishments, who employed dance bands that performed copyrighted compositions without authorization; ${ }^{21}$ on a radio station that ran advertisements for recordings that it knew were not authorized; ${ }^{22}$ on an advertising agency for knowingly promoting the sale of those same infringing recordings, ${ }^{23}$ and on a concert artists' management agency for organizing infringing performances. $^{24}$

But the studios' claim against Sony was of a different order entirely- "unprecedented," the district court called it. ${ }^{25}$ Copyright liability, of either the "vicarious" or "contributory" variety, had never before been imposed on a defendant solely because it manufactured and distributed a device that others used to infringe. ${ }^{26}$ Holding

\footnotetext{
${ }^{19}$ Gershwin Publishing, 443 F.2d at 1162 (emphasis added).

${ }^{20}$ See Shapiro, Bernstein \& Co. v. H.L. Green Co., 316 F.2d 304, 306, 308-10 (2d Cir. 1963).

${ }^{21}$ Dreamland Ball Room, 36 F.2d at 355.

${ }^{22}$ See Screen Gems-Columbia Music, Inc. v. Mark-Fi Records, Inc., 256 F. Supp. 399, 401-02 (S.D.N.Y. 1966).

${ }^{23} \mathrm{Id}$. at 405 .

${ }^{24}$ Gershwin Publishing, 443 F.2d at 1161.

${ }^{25}$ Universal City Studios, Inc. v. Sony Corp. of America, 480 F. Supp. 429, 460 (C.D. Cal. 1979).
}

${ }^{26}$ The closest the Supreme Court had come was in the case of Kalem Co. v. Harper Brothers, 222 U.S. 55 (1911), a case on which Universal relied heavily in its arguments to the district court. In Kalem, a moviemaker made an unauthorized silent movie version of the copyrighted Ben Hur. Id. at 60-61. When sued for infringement, the filmmaker argued that because he had not publicly exhibited the film, but only provided it to others (theater owners) for public exhibition, he was not liable for the infringement. $I d$. at 62 . The Court, speaking through Justice Holmes, rejected this argument by appealing to familiar common law concepts of third-party liability. Courts had already found liquor sellers liable "if the sale was made with a view to the illegal resale," for example, id., and the "view" here was even clearer: "The defendant not only expected but invoked by advertisement the use of its films for dramatic reproduction of the story. That was the most conspicuous purpose for which they could be used, and the one for which especially they were made. If the defendant did not contribute to the infringement, it is impossible to do so.... It is liable on principles ... recognized in every part of the law." Id. at 62-63. See also Elektra 
Sony liable for manufacturing the Betamax would be like holding the manufacturer of a printing press liable for the infringements created by the press - or the manufacturer of nylon stockings liable for the wrongful death of the Boston Strangler's victims. Sony hardly had the kind of ongoing supervisory relationship with its customers (of the principal/agent or employer/employee variety) on which a claim for respondeat superior or other "vicarious" liability was ordinarily built, nor would mere "knowledge" that some customers may break the law ordinarily have sufficed for the imposition of liability of the "aiding and abetting" variety. ${ }^{27}$

The district court rejected the plaintiffs' claim, ${ }^{28}$ because the Betamax was a "staple article of commerce" 29 that could be used "for substantial noninfringing uses" ${ }^{\prime \prime 30}$ - such as recording uncopyrighted television broadcasts or making recordings privileged under the "fair use" doctrine. Sony was no more liable for the wrongdoing of Betamax purchasers than would the seller of a typewriter or a printing press be liable for the infringing conduct of its customers.

The Ninth Circuit reversed, ${ }^{31}$ and the Supreme Court then reversed the Ninth Circuit, reinstating the judgment against Universal in a

Records Co. v. Gem Electronic Distributors, Inc., 360 F. Supp. 821, 825 (E.D.N.Y. 1973) (providing customers of sound recording duplication facilities with copyrighted tapes, blank tapes, and a duplication machine made party liable for customers' infringements).

${ }^{27}$ See supra note 19 and accompanying text.

${ }^{28}$ Sony, 480 F. Supp. at 469-70. To read the 1979 district court opinion in this case is to be reminded how far the technology has progressed during the past quartercentury, as the court felt it necessary to describe, for the reader, the way these strange new devices functioned. See, e.g., $i d$. at 435-36 ("The pause button allows an operator to stop whatever function [-] record, play, fast-forward, reverse [-] the machine is in. ... The fast forward makes it possible to avoid watching on playback a segment that has been recorded. While viewing the tape, an individual can fast forward through an undesired segment.").

${ }^{29} \mathrm{Id}$. at 459 .

${ }^{30} \mathrm{Id}$. at 461 .

${ }^{31}$ Universal City Studios, Inc. v. Sony Corp. of America, 659 F.2d 963, 975-76 (9th Cir. 1981). The Ninth Circuit held, under the traditional definition of vicarious liability, that liability attaches to anyone "who, with knowledge of the infringing activity, induces, causes or materially contributes to the infringing conduct of another," and thus there could be "no doubt" that Sony met the test. Id. at 975. "[I]t cannot be argued," the court remarked, that Sony did not have "knowledge that the Betamax will be used to reproduce copyrighted material," or that the machine was not a material contribution to the offense. Id. 
five to four decision that took it, most unusually, more than two years to hand down. ${ }^{32}$ Justice Stevens's opinion for the Court characterized the lawsuit as an "unprecedented attempt" to "impose copyright liability upon the distributors of copying equipment" and to "expand the protections afforded by the copyright without explicit legislative guidance." ${ }^{\prime \prime 3}$ When a claim of contributory infringement is "predicated entirely on the sale of an article of commerce that is used by the purchaser to infringe," Justice Stevens wrote, the "public interest in access to that article of commerce is necessarily implicated." ${ }^{34}$ The Court saw its task as "strik[ing] a balance between a copyright holder's legitimate demand for effective-not merely

\footnotetext{
${ }^{32}$ Sony Corp. of America v. Universal City Studios, Inc., 464 U.S. 417, 456 (1984). We now know something about the circumstances behind this unusual delay, as a result of the release of Justice Marshall's and Justice Blackmun's papers. The Court was initially disposed to rule in the studios' favor; at the justices' initial conference following oral argument in January 1982, five justices (Blackmun, Marshall, Powell, Rehnquist, and O'Connor) voted to affirm the Ninth Circuit's judgment that Sony's distribution of Betamax recorders rendered it liable as a contributory infringer. Justice Blackmun was given the task of writing a majority opinion for the Court. But Justice Stevens, a mere six days after oral argument, circulated a memorandum containing the "basic outline" of the argument that he expected "to emphasize in dissent" (a memorandum that would ultimately become the majority opinion). The next several months saw a flurry of memos, circulating drafts, and shifting views, as Justices Powell and $\mathrm{O}^{\prime}$ Connor, who had formed part of the initial majority to affirm, began to waver. Justice O'Connor's vote was to prove decisive; in June, she informed the chief justice that she had now adopted "a 'middle" position on the merits and a movement toward a more restrictive stance on contributory infringement," and she recommended calling for re-argument. Although the Stevens opinion appeared to command a majority of the Court by this point (Burger, Stevens, Brennan, White, and O'Connor, and possibly Powell), the Court ran out of time, and the case was set for re-argument the following term. Re-argument took place on October 3, 1983, and there was little subsequent change in the justices' positions. The decision was announced January 17, 1984, with Stevens, Brennan, White, O'Connor, and Burger in the majority, and Blackmun, Powell, Marshall, and Rehnquist dissenting.

For informative and entertaining accounts of the behind-the-scenes story of the Sony decision, see generally Jonathan Band \& Andrew J. McLaughlin, The Marshall Papers: A Peek Behind the Scenes at the Making of Sony v. Universal, 17 Colum.VLA J.L. \& Arts 427 (1993); Paul Goldstein, Copyright's Highway: The Law and Lore of Copyright from Gutenberg to the Celestial Jukebox 149-58 (1994); Jessica Litman, The Sony Paradox 11-23 (February 25, 2005), available at http: / / www.law. wayne.edu/litman/papers/Sonyparadox.pdf (visited July 29, 2005); Jesse M. Feder, Is Betamax Obsolete? Sony Corp. of America v. Universal City Studios, Inc. in the Age of Napster, 37 Creighton L. Rev. 859, 874-75 (2004).

${ }^{33}$ Sony, 464 U.S. at 431.

${ }^{34} \mathrm{Id}$. at 440 .
} 
symbolic-protection of the statutory monopoly, and the rights of others freely to engage in substantially unrelated areas of commerce." ${ }^{\prime \prime 35}$ Drawing, by analogy, from the doctrine of contributory patent infringement, ${ }^{36}$ which exempts the sale of "staple articles of commerce" from liability, the Court held that "the sale of copying equipment, like the sale of other articles of commerce, does not constitute contributory infringement if the product is . . capable of substantial noninfringing uses. ${ }^{\prime 37}$

The Court went on to hold that the Betamax was indeed "capable of substantial noninfringing uses," of two kinds: authorized timeshifting and unauthorized time-shifting. As to the former: "[M]any important producers of national and local television programs" - the Court here referred specifically to "televised sports events, religious broadcasts, and educational programming such as Mister Rogers' Neighborhood" - "find nothing objectionable about the enlargement in the size of the television audience that results from the practice of time-shifting for private home use." ${ }^{\prime 38}$ A finding of contributory infringement would "frustrate the interests" of those broadcasters. ${ }^{39}$ Because at least some copyright holders "welcome the practice" of home time-shifting, "the business of supplying the equipment that makes such copying feasible should not be stifled simply because the equipment is used by some individuals to make unauthorized reproductions of [plaintiffs'] works. ${ }^{\prime 40}$

And even where the time-shifting recording is not authorized by the copyright holder(s), the Court reasoned, the recording may be noninfringing because it is covered by the "fair use" doctrine. Copying "for a commercial or profit-making purpose" is "presumptively ... unfair"; ;1 but private, non-commercial home taping is a different matter. "The record amply supports the District Court's conclusion that home time-shifting is fair use",; ${ }^{2}$ the studios "failed to carry their burden" of demonstrating that private time-shifting was

\footnotetext{
${ }^{35} \mathrm{Id}$. at 442 .

${ }^{36} I d$. at $439-41$.

${ }^{37} I d$. at 442 (emphasis added).

${ }^{38} \mathrm{Id}$. at 446 .

${ }^{39} \mathrm{Id}$.

${ }^{40} I d$. (emphasis added).

${ }^{41}$ Id. at 448 .

${ }^{42} \mathrm{Id}$. at 454 .
} 
"harmful" or "adversely affect[ed] the potential market for the copyrighted work." 43

\section{Pause: Sony, Reconsidered}

Most interesting, in hindsight, is not that the courts ultimately rejected the plaintiffs' attempt to extend the principles of third-party liability to Sony-it is that they had so much difficulty doing so. The Supreme Court clearly found the case to be one of unusual difficulty, and of the thirteen judges who considered the studios' claim as it made its way up the appellate ladder, seven actually sided with the studios. But today, one must search long and hard to find anyone, on either side of the "copyfights," arguing that Sony was wrongly decided, ${ }^{44}$ that we all would actually have been better off had the holders of copyrights in television shows and movies been able to enjoin the sale and distribution of the VCR, or to force VCR manufacturers to compensate them for each VCR sold. ${ }^{45}$

\section{${ }^{43} \mathrm{Id}$. at 451 .}

${ }^{44}$ For instance, in over 55 amicus briefs submitted in the Grokster litigation to the Court, not one urges the Court to overrule the Sony result. See Electronic Frontier Foundation, MGM Studios Inc. v. Grokster, Ltd. Resources Website, http://www. eff.org/IP/P2P /MGM_v_Grokster (visited July 29, 2005). Even Sony's sharpest detractors (see generally Brief of Professors Menell, Nimmer, Merges, and Hughes in Support of Petitioners, MGM Studios Inc. v. Grokster, Ltd., 125 S. Ct. 2764 (2005) (No. 04-480), and Brief of Amicus Curiae Law Professors, Economics Professors, and Treatise Authors as Amici Curiae in Support of Petitioners, MGM Studios Inc. v. Grokster, Ltd., 125 S. Ct. 2764 (2005) (No. 04-480)) reject such a suggestion. See, e.g., Brief of Menell et al., supra, at 10 ("These determinations relieved much of the pressure on delineating the contours of indirect liability. Once that determination was in place, even under the dissent's 'primary use' test, the VCR would not have violated the Copyright Act. Accepting the majority's conclusion that time shifting by users fell within the bounds of the fair use defense, the net balance strongly favored continued marketing of the VCR technology. Thus, the indirect liability standard selected by the majority in Sony was not critical to the outcome of the case.").

${ }^{45}$ Sony looks even better when contrasted with the counterfactual world in which Justice O'Connor does not switch sides and Sony loses. The law of the land (as pronounced in Justice Blackmun's now-majority opinion) would then be: "off-theair recording is an infringement of copyright," and unless "a significant portion of [a] product's use is noninfringing," the manufacturers and sellers are contributorily liable "for the product's infringing uses." Compare Sony Corp. of America v. Universal City Studios, Inc., 464 U.S. 417, 490, 491 (1984) (Blackmun, J., dissenting). It is impossible, of course, to know exactly how these principles would have played themselves out over time, but given that the VCR had failed this test, what would the developers of follow-on copying technologies-DVD recorders, for example, or music-processing software, or the iPod, or even the basic "copying" technologies at the heart of the Internet's routers-have done? How much of a copyright royalty 
In retrospect, knowing the rest of the VCR story, Sony looks like a win for both sides; by declining Sony's invitation to limit distribution of the VCR on a theory of third-party infringement, the Court allowed the cultural and economic potential of the VCR to be fully realized-in ways that turned out to be enormously beneficial for copyright holders, component manufacturers, and the public alike. The VCR, in the end, was capable of noninfringing uses that no one (including the plaintiffs and the justices) had foreseen-for example, the playing of pre-recorded movies produced and distributed by the motion picture industry itself. It was not the Boston Strangler after all; on the contrary, it was the blind date that turned out to be Hollywood's Prince Charming. Instead of trying to block the distribution of VCRs, the movie studios probably should have given them away for free. ${ }^{46}$

But while Sony's outcome has proven uncontroversial, its reasoning has become, if anything, more obscure over time. Perhaps because it began life as a dissenting opinion, or perhaps because of the difficulties attendant upon keeping a fragile, fractured coalition together, the Court's opinion was more than a little obscure ${ }^{47}$ Most fundamentally: what exactly is the test to be applied to determine whether a device can withstand a charge of contributory infringement? According to the Sony majority:

[T] he sale of copying equipment, like the sale of other articles of commerce, does not constitute contributory infringement if the product is [1] widely used for legitimate, unobjectionable purposes. Indeed, it need merely be [2] capable of substantial noninfringing uses... . The question is thus whether the Betamax is [3] capable of commercially significant noninfringing

would they have had to pay, or how much copyright liability insurance would they have needed to secure, in order to distribute their products? And how much of a drag would that have been on the development of those technologies?

${ }^{46} \mathrm{In}$ fact, there is reason to think that Internet file-sharing technology may be good for the music industry. See Jesse Walker, Music for Nothing: Why Napster Isn't the End of the World or Even the Music Industry, Reason, October 2000, available at http://reason.com/0010/fe.jw.music.shtml (visited July 29, 2005).

${ }^{47} \mathrm{So}$, too was its language. See A \& M Records, Inc. v. Napster, Inc., 239 F.3d 1004, 1022-23 (9th Cir. 2001) (noting that Supreme Court itself in Sony imprecisely used term "vicarious liability"). Stevens's analysis combined, in Jessica Litman's words, "his own solicitude for private noncommercial copying[,] Justice Brennan's distinction between time-shifting and library building, and Justice O'Connor's preference for the staple article of commerce doctrine." Litman, The Sony Paradox, supra note 32, at 23 . 
uses.... [W] need only consider whether on the basis of the facts as found by the district court [4] a significant number of them would be non-infringing.... [W] need not give precise content to the question of how much use is commercially significant. ... The Betamax is ... [[2], again] capable of substantial noninfringing uses. ${ }^{48}$

How is the "substantiality" or "commercial[ ] significan[ce]" of noninfringing use to be measured? What did the Court mean by saying that a device only has to be "merely capable" of such use to benefit from the Sony safe harbor?

And second: what is the relationship between the Sony safe harbor (however defined) and other doctrines of third-party copyright liability? Is Sony an immunity from copyright liability? Even if a defendant otherwise meets the requirements for "contributory" or "vicarious" liability? In some circumstances but not others?

After Sony, the formula for third party liability looks basically like this:

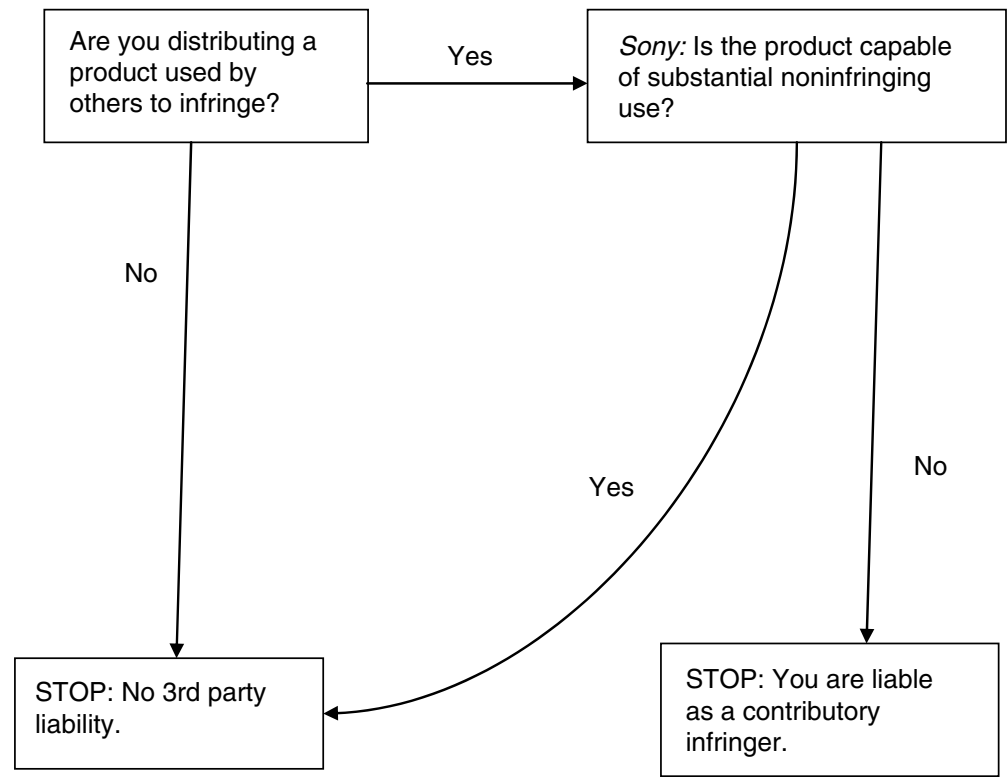

Figure 1. Copyright liabiliy post-Sony for distributing devices used by third parties to infringe.

${ }^{48}$ Sony, 464 U.S. at 442, 456 (emphasis added). 


\section{Fast Forward: Napster}

The first high-profile, high stakes legal battle to press the questions left in Sony's wake began, much like the legal battle over home videotaping had begun, with the advent of a new technology that empowered consumers to reproduce and distribute entertainment "content" with unprecedented ease. Napster, an Internet start-up founded in May of 1999 by a college freshman, developed software to facilitate the exchange of files from one Internet user to another. Dubbed "MusicShare," the software was distributed to users for free over the Internet, and it allowed online users to make the MP3 (and other) files stored on their hard drives available in real time to other online users. ${ }^{49}$ Napster stored the names of available MP3 files on its servers in a massive collective index that was updated continuously as users logged on and off the system; the files themselves remained stored on users' hard drives. Thus, the file transfers enabled by the MusicShare software were direct from user-to-user, or, in network parlance, peer-to-peer.

${ }^{49}$ [The Napster system] works, more or less, as follows. You download the MusicShare software. You run the software on your computer. It scans your hard disk and compiles a directory of the names of the music files it finds there. It then sends that directory - not the files themselves, just the list of file names-back to Napster's "home" computer, the Napster server, where it is placed into a database, along with the directories of all of the other Napster users who have gone through the same process (70 million or so at its peak).

The next time you (or any of the 70 million) log onto the Internet, your computer, in addition to doing whatever else it is doing, sends a message to the Napster server: "User John_Doe here-I've just logged on to the Internet, and my 'Internet Protocol address' - the number my Internet Service Provider has assigned to me so that I can send and receive messages over the Internetis [255.255.4.11]." The Napster server updates the database with this information, so that, in addition to the names of the music files on each Napster user's hard disk, it now contains information about whether each user is, or is not, currently logged on, and the Internet address of all users who are currently online.

So far, so good. If you then find yourself, on some dark and lonely night, desperate to hear, say, Bob Dylan's version of the Stanley Brothers' classic "Rank Stranger," you send a query to the Napster server: "Does your database list any machines that have a copy of this song? If so, can you please provide me with the list of those that are currently logged onto the Internet-with their IP addresses?" . . . When the server sends you back that list, the Napster software conveniently lets you send a message directly to any of those machines-because you have their IP addresses you can easily contact themrequesting the file in question; a copy of the file is then transmitted directly from that remote machine to yours.

David G. Post, His Napster's Voice, in Copy Fights: The Future of Intellectual Property in the Information Age 107, 107-08 (Clyde Wayne Crews \& Adam Thierer eds., 2002). 
Almost overnight, the Internet start-up that began as the brainchild of a teenager who wanted to share music with his friends grew into a service with fifty-eight million users with access to as many as a billion MP3 files..$^{50}$ Napster was a phenomenon; at the time, the fastest-growing software application ever. Like the VCR before it, it quickly drew the attention of the music industry. Within just months of rocketing into the dot-com stratosphere, Napster was sued for contributory and vicarious copyright infringement by a coalition of music industry plaintiffs, including major record companies and music publishers. ${ }^{51}$

The Napster ${ }^{52}$ plaintiffs filed suit in district court in July 2000 seeking an injunction against Napster's continued operation of its file-sharing service. ${ }^{53}$ Napster, not surprisingly, invoked the Sony doctrine: like the VCR, it argued, its system was capable of substantial or commercially significant noninfringing uses, ${ }^{54}$ and, therefore, like Sony, it could not be held contributorily liable for its users' direct infringements. ${ }^{55}$

${ }^{50}$ Adam Cohen, Napster the Revolution: A Crisis of Conduct, CNN/Time, Sept. 25, 2000, available at http://www.cnn.com/ALLPOLITICS/time/2000/10/02/ revolution.html (visited July 24, 2005).

${ }^{51}$ Among the plaintiffs, ironically, was Sony, which, in the years between its victory against Universal and the birth of Napster, had transformed itself from an electronics manufacturer ("Sony Corporation of America") into an entertainment giant ("Sony Music Entertainment, Inc."). The proverbial shoe was now on the other foot for the company that had once championed liberal fair use rights for entertainment consumers.

${ }^{52}$ A \& M Records, Inc. v. Napster, Inc., 114 F. Supp. $2 d 896$ (N.D. Cal. 2000).

${ }^{53}$ Continuing in the tradition of droll comparisons begun by the MPAA's Valenti, the Recording Industry Association of America (RIAA) wrote in its brief: "The truth is, the making and distributing of unauthorized copies of copyrighted works by Napster users is not 'sharing,' any more than stealing apples from your neighbor's tree is 'gardening."' See John Borland, Recording Industry Calls Napster Defense "Baseless," CNET News, July 13, 2000, available at http://news.com.com/Recording + industry + calls + Napster + defense + baseless /2100-10233-243162.html (last visited July 24, 2005).

${ }^{54} 114$ F. Supp. $2 \mathrm{~d}$ at 912 . Napster pointed to three noninfringing uses of its peerto-peer music sharing system: sampling (the process whereby users download songs to decide whether they want to buy the CDs containing the songs), space-shifting (the process whereby users copy songs they've already legally purchased onto a portable audio player or other device), and the authorized distribution of new artists' work. Id. at 913.

${ }^{55}$ Id. at 918. 
The district court rejected Napster's proffered noninfringing uses as disingenuous, commercially insignificant, and, in the case of new artist promotion, a mere "afterthought." ${ }^{156}$ Unable to find that the Napster system had any "commercially significant noninfringing uses," the district court denied Napster the benefit of the Sony safe harbor. ${ }^{57}$ The court went on to hold that the plaintiffs were likely to succeed on their contributory infringement claim because they could prove both required elements of the claim, i.e., actual or constructive knowledge of users' illegal conduct, and a "material contribution" to the infringing activity. ${ }^{58}$ As far as "knowledge" was concerned, the court found that Napster knew or should have known that its system was being used to infringe: Napster executives had themselves used the software to download infringing files; Napster had promoted its web site with screen shots listing infringing titles; memos between Napster executives acknowledged that users were exchanging "pirated music"; and plaintiffs had provided Napster with actual notice that it was providing access to thousands of infringing files..$^{59}$ The plaintiffs' proof of Napster's generalized knowledge of infringing uses was sufficient, the court held, because "[t]he law does not require actual knowledge of specific acts of infringement." 60 And as for "material contribution," the court found adequate evidence of Napster's contribution in the fact that it supplied "support services" for its users in the form of proprietary software; a central database of songs; a means of identifying where the songs were located on the system; a search engine; servers; and

${ }^{56} \mathrm{Id}$. at $916-18$.

${ }^{57} \mathrm{Id}$. at 917 .

${ }^{58} \mathrm{Id}$. at 919 .

${ }^{59} \mathrm{Id}$. at 918 .

${ }^{60} \mathrm{Id}$. (citing Gershwin Publishing Corp. v. Columbia Artists Management, Inc., 443 F.2d 1159, 1163 (2d Cir. 1971)). 
the means of connecting to other users' computers. ${ }^{61}$ Finding that the plaintiffs would likely succeed on the merits of their third-party infringement claims, the district court enjoined Napster "from engaging in, or facilitating others in copying, downloading, uploading, transmitting, or distributing plaintiffs' copyrighted musical compositions and sound recordings, protected by either federal or state law, without express permission of the rights owner." ${ }^{\prime 62}$ The court charged Napster with the prodigious task of "insur[ing] that no work owned by plaintiffs which neither defendant nor Napster users have permission to use or distribute is uploaded or downloaded on Napster." ${ }^{\prime 3}$ The day after the injunction, traffic on Napster's website increased seventy-one percent, as users rushed to download MP3s before the music died. ${ }^{64}$

On appeal, the Ninth Circuit affirmed, finding that injunctive relief in favor of the plaintiffs was "not only warranted but required." 65 It found fault, however, with the district court's application of Sony. The district court had been incorrect when it held that Napster failed to show any commercially significant noninfringing uses for its system; it had "improperly confined the use analysis to current uses, ignoring the system's capabilities [and] plac[ing] undue weight

${ }^{61} I d$. at 920. The court also held that the plaintiffs were likely to succeed on the merits of their vicarious copyright infringement claim. Napster had both the ability to "police" its users' infringing conduct and a direct financial interest in their infringing activity. Id. at 921 . The court found that Napster could block, and had in fact already blocked, access to the system by users who had provided others with access to infringing files. $I d$. at 920 . The fact that Napster had already blocked infringing users established, in the eyes of the court, that Napster had the means to discern both which users and which files were infringing. Id. With respect to Napster's financial interest in its users' conduct, the court found evidence in the record that, although Napster generated no revenue at the time the plaintiffs sought relief, the company planned to derive revenue from increases in the number of Napster users. So long as Napster had "economic incentives for tolerating unlawful behavior," id. at 921, the court held, it had a demonstrable direct financial interest in its users' infringing conduct.

${ }^{62}$ Id. at 927 .

${ }^{63} \mathrm{Id}$.

${ }^{64}$ Napster: Stealing or Sharing, CNN Online, available at http://www.cnn.com/ SPECIALS/2001/napster/timeline.html (visited July 24, 2005).

${ }^{65}$ A \& M Records, Inc. v. Napster, Inc., 239 F.3d 1004, 1027 (9th Cir. 2001). 
on the proportion of current infringing use as compared to current and future noninfringing use." ${ }^{\prime 66}$

But meeting the Sony "staple article of commerce" standard, the court continued, did not immunize Napster from liability. Sony stood for the proposition that the knowledge of the infringing acts required to sustain a claim for contributory infringement would not be imputed to a defendant who merely distributed a copying technology that was "capable of substantial noninfringing use." tem operator cannot be liable for contributory infringement merely because the structure of the system allows for the exchange of copyrighted material," absent "specific information which identifies infringing activity." ${ }^{\prime 68}$ But where the system operator "learns of specific infringing material available on his system and fails to purge such material from the system," the operator "knows of and contributes to direct infringement." ${ }^{\prime \prime 9}$

In Napster's case, knowledge of infringing activity did not need to be imputed; the court found that Napster, unlike Sony, had "actual knowledge of specific acts of infringement, ${ }^{\prime 70}$ and, in the face of that knowledge, it had failed to "block access to the system by suppliers of infringing material" or "remove the material."71 That the Napster software was "capable of commercially significant [lawful] use" was therefore irrelevant; actual knowledge that infringements were taking place, plus the ability and refusal to act upon that knowledge to prevent the infringements, eliminated any need to impute knowledge to Napster, and was a sufficient basis for the imposition of liability independent of the (now-narrowed) Sony safe harbor.

${ }^{66} \mathrm{Id}$. at 1021 (emphasis added).

${ }^{67}$ See $i d$. at 1020 ("The Sony Court declined to impute the requisite level of knowledge where the defendants made and sold equipment capable of both infringing and 'substantial noninfringing uses."') (citing Sony Corp. of America v. Universal City Studios, Inc., 464 U.S. 417, 422 (1984)).

${ }^{68}$ Id. at 1021 .

${ }^{69} \mathrm{Id}$. (citing Religious Technology Center v. Netcom On-Line Communication Services, Inc., 907 F. Supp. 1361, 1374 (N.D. Cal. 1995)).

${ }^{70} I d$. (emphasis added). The court referred specifically to the notices that the plaintiffs had delivered to Napster, informing it of "more than 12,000 infringing files" listed in Napster's database. See id. at 1022 n.6.

${ }^{71} I d$. at 1022 . 
After Napster, the formula for third party liability looks a little more complicated than it had after Sony, but it retains the same basic structure:

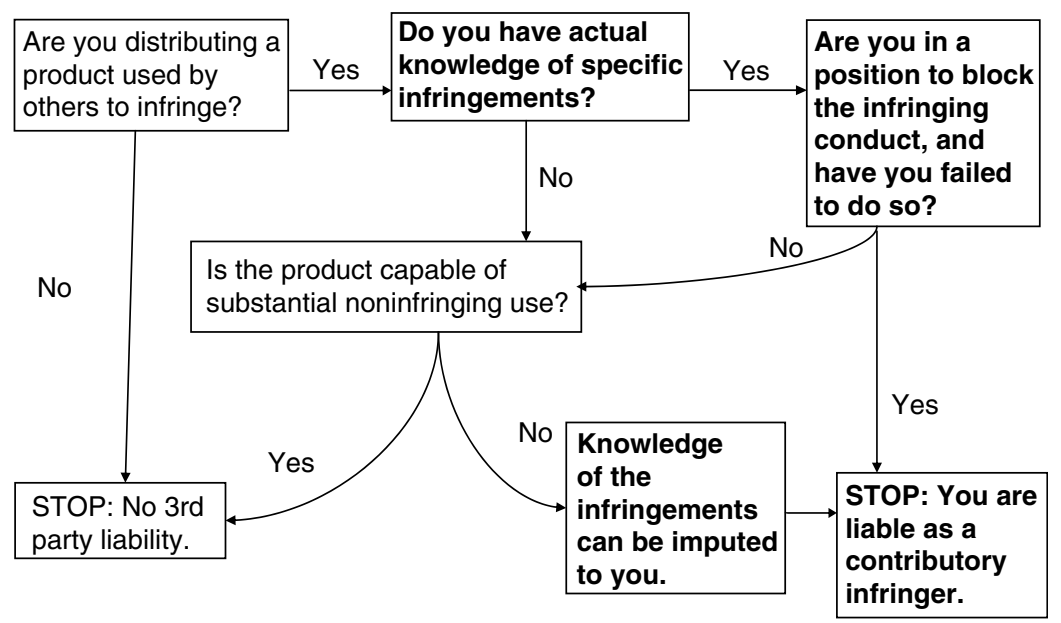

Figure 2. Copyright liability for distributing devices used by third parties to infringe post-Napster (new rules in bold).

As a practical matter, the Ninth Circuit's decision brought an end to the Napster phenomenon. The system's users disappeared as quickly as they had arrived, taking all the free music with them. During the pendency of the litigation, Napster's diminishing assets were acquired by Bertelsmann, one of the plaintiffs in the case. ${ }^{72}$ Through the magic of the market, the industry's latest antagonist became its hottest new property. The momentum that appeared to be driving the Napster case inexorably toward the Supreme Court quickly dissipated, but the legal battle over peer-to-peer file sharing had been joined, and Napster, like Sony before it, would live to fight (for the other side) another day.

${ }^{72}$ See Amy Doan, Napster, Bertelsmann Deal Gives Labels a Fright, Forbes.com, Oct. 31, 2000, http:/ /www.forbes.com/2000/10/31/1031napster.html. 


\section{Play: Grokster}

Even before the ink on the Napster opinion was dry, new filesharing technologies were being deployed over the Internet. Grokster and StreamCast were among the developers of a new generation of decentralized, or "distributed," peer-to-peer file-sharing software. Instead of using, as Napster did, a central server to store a master index of all files available on the network, the Grokster/StreamCast systems do their indexing "on the fly," without any need to communicate with a central machine. ${ }^{73}$ In a rush to make Napster's loss their gain, Grokster and StreamCast-much to their subsequent detriment, as we will see in a moment-began marketing their systems expressly to former Napster users who had been left high and dry by the latter's demise.

Once again, a coalition of music industry copyright holders sued, seeking an injunction against the continuing distribution of the software on the grounds that it constituted both contributory and vicarious infringement. The defendants argued, in essence, that their software was more like a VCR than it was like the Napster software, at least for the purpose of determining third-party liability for copyright infringement. Because they used no central index database or central server, Grokster and StreamCast claimed that they had no "actual knowledge of specific infringing acts," and, even if they had, could do nothing to prevent users from infringing. ${ }^{74}$ Nor could knowledge be imputed to them, they maintained, insofar as their software, like Napster's (and the VCR), was "capable of substantial noninfringing uses.' ${ }^{\prime 75}$

The district court agreed, granting the defendants' motion for summary judgment on the issue of third-party copyright infringe-

${ }^{73}$ Good descriptions of the technical details of the Grokster and StreamCast systems can be found in MGM Studios Inc. v. Grokster, Ltd., 380 F.3d 1154, 1158-60 (9th Cir. 2004), and in MGM Studios Inc. v. Grokster, Ltd., 125 S. Ct. 2764, 2770-74 (2005).

${ }^{74}$ MGM Studios Inc. v. Grokster, Ltd., 259 F. Supp. 2d 1029, 1037 (C.D. Cal. 2003).

${ }^{75} \mathrm{Id}$. at 1035. 
ment, ${ }^{76}$ and the Ninth Circuit affirmed. The court of appeals held that the plaintiffs had not established that defendants had "specific knowledge of infringement at a time at which they contributed to the infringement, and failed to act upon that information." ${ }^{\prime 77}$ And because the defendants' products were "capable of substantial or commercially significant noninfringing uses, ${ }^{\prime \prime 78}$ knowledge of the infringements could not be imputed to them. They could, therefore, avail themselves of the Sony safe harbor, and they were absolved of contributory copyright infringement. ${ }^{79}$

The Supreme Court unanimously reversed, adding another threshold requirement to the Sony safe harbor: not only must the copying technology in question be capable of substantial noninfringing uses, it cannot have been distributed "with the object of promoting its use to infringe copyright, as shown by clear expression or other affirmative steps taken to foster infringement." ${ }^{180}$ In other words, regardless of whether the copying technology itself meets the Sony "staple article of commerce" test, a distributor who "actively induce[s] infringements ${ }^{\prime \prime 81}$ is liable for the resulting acts of infringement by third parties. The focus of this threshold "inducement" inquiry is not on the technology itself at all (or the extent to which

\footnotetext{
${ }^{76}$ In its opinion, the district court noted that "[b]ecause Plaintiffs principally seek prospective injunctive relief, the Court at this time considers only whether the current versions of Grokster's and StreamCast's products and services subject either party to liability. This Order does not reach the question whether either Defendant is liable for damages arising from past versions of their software, or from other past activities." Id. at 1033 (emphasis added). The precise meaning of this limitation is somewhat obscure.

${ }^{77} 380$ F.3d at 1162.

${ }^{78} I d$.

${ }^{79}$ The appeals court made the following reference to the somewhat unusual procedural posture in which it found the case (see note 76 , supra):

Resolution of these issues does not end the case. As the district court clearly stated, its decision was limited to the specific software in use at the time of the district court decision. The Copyright Owners have also sought relief based on previous versions of the software, which contain significant-and perhaps crucial-differences from the software at issue. We express no opinion as to those issues.

Id. at 1166 .

${ }^{80}$ MGM Studios Inc. v. Grokster, Ltd., 125 S. Ct. 2764, 2780 (2005) (emphasis added).

${ }^{81} I d$. at 2791 (Breyer, Stevens, and O'Connor, JJ., concurring).
} 
it is capable of noninfringing use) but on the "purposeful, culpable expression and conduct" of the technology's distributors. ${ }^{82}$

The Ninth Circuit read Sony to mean that "whenever a product is capable of substantial lawful use, the producers can never be held contributorily liable for third parties' infringing use of it ... unless [they] had 'specific knowledge of infringement at a time at which they contributed to the infringement, and failed to act upon that information." ${ }^{\prime \prime 83}$ In this, the Court said, they erred:

[Sony] dealt with a claim of liability based solely on distributing a product with alternative lawful and unlawful uses, with knowledge that some users would follow the unlawful course [,] [and held] that the product's capability of substantial lawful employment should bar the imputation of fault and consequent secondary liability for the unlawful acts of others. $^{84}$

Sony prohibits courts from imputing an intent to cause infringement "solely from the design or distribution of a product capable of substantial lawful use," ${ }^{\prime \prime 5}$ while it allows courts to so presume if the defendant distributes an article that is "'good for nothing else' but infringement." ${ }^{\prime \prime 6}$ But either way, the Court concluded, Sony was "never meant to foreclose rules of fault-based liability derived from the common law," ${ }^{\prime \prime 7}$ and if there is "direct evidence of unlawful purpose ... [n]othing in Sony requires courts to ignore [it]." ${ }^{\prime 88}$

Looking at the record before it, the Court saw ample direct evidence of an unlawful purpose; Grokster and StreamCast had each "clearly voiced the objective that recipients use it to download copyrighted works," 199 each "took active steps to encourage infringement," ${ }^{190}$ and each, "unlike the manufacturer and distributor in Sony,

${ }^{82} I d$. at 2870 .

${ }^{83} I d$. at 2778 (quoting Grokster, 380 F.3d at 1162).

${ }^{84} \mathrm{Id}$. at 2782 (emphasis added).

${ }^{85} \mathrm{Id}$. at 2779 (emphasis added).

${ }^{86} I d$. at 2777 (quoting Canda v. Michigan Malleable Iron Co., 124 F. 486, 489 (6th Cir. 1903)) (emphasis added).

${ }^{87}$ Id. at 2779 .

${ }^{88} I$ d.

${ }^{89} I d$. at 2767.

${ }^{90} \mathrm{Id}$. 
acted with a purpose to cause copyright violations." ${ }^{\prime 91}$ Among the "words and deeds [that] show [defendants'] purpose to cause and profit from third-party acts of copyright infringement":

- each company showed itself "to be aiming to satisfy a known source of demand for copyright infringement, the market comprising former Napster users," ${ }^{2}$ by "beam[ing] onto the computer screens of users of Napster-compatible programs ads urging the adoption of [defendants'] OpenNap program, which was designed, as its name implied, to invite the custom of patrons of Napster, then under attack in the courts for facilitating massive infringement",, 93

- each of the defendants "communicated a clear message [of encouragement] by responding affirmatively to requests for help in locating and playing copyrighted materials",;94

- there were "unequivocal indications of unlawful purpose in the internal communications and advertising designs aimed at Napster users. ${ }^{\prime 95}$

In the face of such actual proof of an unlawful purpose, there was no need for the Court to decide whether the Grokster or StreamCast systems were or were not "staple articles of commerce" under Sony:

We do not revisit Sony further, as MGM requests, to add a more quantified description of the point of balance between protection and commerce when liability rests solely on distribution with knowledge that unlawful use will occur. It is enough to note that the Ninth Circuit's judgment rested on an erroneous understanding of Sony and to leave further consideration of the Sony rule for a day when that may be required. ${ }^{96}$

${ }^{91} I d$. at 2781 .

${ }^{92} \mathrm{Id}$. at 2769 .

${ }^{93} \mathrm{Id}$. at 2780 .

${ }^{94} I d$. at 2781 .

${ }^{95} \mathrm{Id}$.

${ }^{96} \mathrm{Id}$. at $2778-79$. 
After Grokster, then, the model for third-party liability incorporates inducement liability and looks like this:

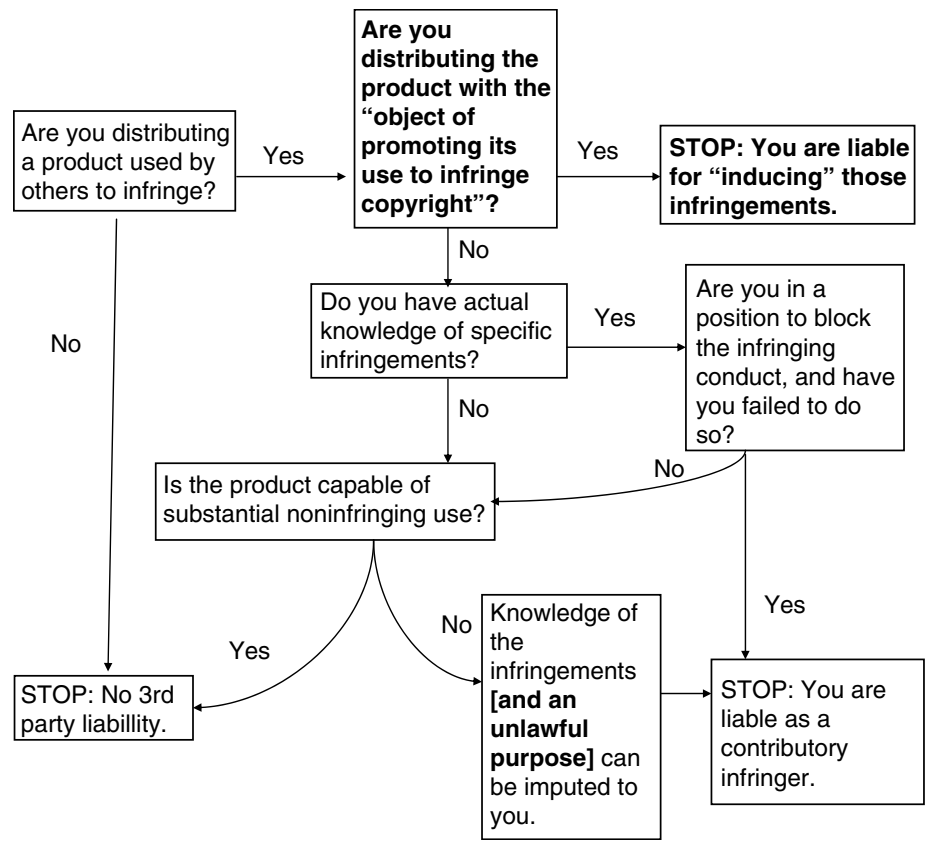

Figure 3. Copyright liability for distributing devices used by third parties to infringe post-Grokster (new rules in bold).

\section{Final Words}

Precisely how significant the Grokster decision will be for the future course of file sharing on the Internet remains to be seen. The next generation of peer-to-peer file-sharing systems is already being widely deployed, ${ }^{97}$ and one can confidently predict that distributors and developers will, from now on, be far more circumspect in their

${ }^{97}$ See, e.g., the BitTorrent system, described at http:/ /www.bittorrent.com/introduction.html (last checked August 1, 2005). BitTorrent is even more radically decentralized than the Grokster and StreamCast systems; not only is there no central server or master index, but requests for individual files are themselves distributed across the user network, so that each user in possession of the requested file contributes only a small piece of the file to the requestor. 
promotional and marketing materials. ${ }^{98}$ But what of that? What if you're a software developer and you're just distributing file-sharing software, with no evidence that you "actively encourage" your users to infringe (though many, in fact, do)? What if Grokster/StreamCast had not been so overt in their encouragement of infringement; would their systems have been held to be "capable of substantial noninfringing uses" and, if so, would Sony have protected them? What about the next case in this sequence, which will likely involve less culpable conduct on the part of the defendant manufacturer/distributor? The opinion for the unanimous Court is silent on how these questions might be and should be resolved. That the Grokster opinion leaves considerable uncertainty with regard to these issues is clear from an examination of the separate concurring opinions.

Three justices (in a concurring opinion authored by Justice Ginsburg, joined by Rehnquist and Kennedy) would not have absolved Grokster and StreamCast of liability, even if there had been no direct evidence of inducement, on the ground that their software was not a "staple article of commerce" with "substantial non-infringing uses" - at least, not on this record. Reviewing the evidence of noninfringing uses presented by the defendants in considerable detail-

\footnotetext{
${ }^{98}$ The following colloquy, which took place at oral argument in the Grokster case, reflects some of these questions:

JUSTICE SCALIA: The inducement point doesn't get you very far. Presumably a successor to Grokster, or whatever this outfit is called, could simply come in and not induce anybody but say, you know, "We're setting up the same system," know very well what people are going to use it for, but not induce them. And that would presumably be okay.

MR. CLEMENT [Acting Solicitor General, appearing for the United States in support of the record industry petititoners]: I think that's potentially right ... Transcript of Oral Argument at 25, MGM Studios Inc. v. Grokster, Ltd., No. 04-480, available at http://www.supremecourtus.gov/oral_arguments/argument_ transcripts/04-480.pdf (last visited July 29, 2005). Subsequently, at the beginning of his rebuttal argument, Donald Verrilli, counsel for MGM and the other record industry petitioners, adverted back to Justice Scalia's question:

MR. VERRILLI: Why is inducement not enough? It's not enough because, as Justice Scalia suggested, these companies already operate in the shadows, and a ruling here ... that inducement is the only available ground of liability, would just need them to paper over-you know, we do have some paper evidence here, a paper trail here, but ... they just won't exist next time. And it's just-it's just not enough.

Id. at $51-52$.
} 
and finding it a "motley collection of declarations," "99 "some of them hearsay,",100 "mostly anecdotal,"101 and "sometimes obtained secondhand"102 — they found it insufficient, "in the face of evidence, proffered by MGM, of overwhelming use of Grokster's and StreamCast's software for infringement," to justify permitting the defendants to find refuge in Sony's safe harbor:

[W] hen the record in this case was developed, there was evidence that Grokster's and StreamCast's products were, and had been for some time, overwhelmingly used to infringe, and that this infringement was the overwhelming source of revenue from the products. Fairly appraised, the evidence was insufficient to demonstrate, beyond genuine debate, a reasonable prospect that substantial or commercially significant noninfringing uses were likely to develop over time. On this record, the District Court should not have ruled dispositively on the contributory infringement charge by granting summary judgment to Grokster and StreamCast. ${ }^{103}$

Three other justices (Justice Breyer, joined by Stevens (Sony's author) and $\mathrm{O}^{\prime}$ Connor) disagreed. In their view, the evidence "shows that Grokster passes Sony's test"; it is "capable of substantial or commercially significant non-infringing uses." ${ }^{104}$ The emphasis, for the justices joining in the Breyer concurrence, is on the "capable." Even using data supplied by MGM's experts, Justice Breyer noted, around ten percent of the files shared on the Grokster/StreamCast systems were noninfringing. This is small, in quantitative terms, but

[i]mportantly, Sony also used the word "capable," asking whether the product is "capable of" substantial noninfringing uses. Its language and analysis suggest that a figure like $10 \%$, if fixed for all time, might well prove insufficient, but that such a figure serves as an adequate foundation where there is a reasonable prospect of expanded legitimate uses over time. And its language also indicates the appropriateness of

\footnotetext{
${ }^{99}$ Grokster, 125 S. Ct. at 2786 n.3 (Ginsburg, Kennedy, JJ., Rehnquist, C.J., concurring).

${ }^{100} \mathrm{Id}$. at 2785 .

${ }^{101} I d$.

${ }^{102} I d$.

${ }^{103} I d$. at 2786 .

${ }^{104} \mathrm{Id}$. at 2788 (Breyer, Stevens, O'Connor, JJ., concurring).
} 
looking to potential future uses of the product to determine its "capability.",105

Moreover, Justice Breyer found, the record here "reveals a significant future market for noninfringing uses of Grokster-type peer-topeer software."106 Noting that file-sharing software "permits the exchange of any sort of digital file-whether that file does, or does not, contain copyrighted material," these three justices thought it likely that, "[a]s more and more uncopyrighted information is stored in swappable form ... lawful peer-to-peer sharing will become increasingly prevalent" for such tasks as "swapping research information (the initial purpose of many peer-to-peer networks); public domain films . . . ; historical recordings and digital educational materials ... ; digital photos ... ; 'shareware' and 'freeware'; secure licensed music and movie files; news broadcasts past and present; user-created audio and video files; and all manner of free 'open content' works collected by Creative Commons." ${ }^{107}$ The "foreseeable development of such uses, when taken together with an estimated $10 \%$ noninfringing material, is sufficient to meet Sony's standard." 108

We had hoped to learn from the Court's opinion in Grokster whether a distributor of a copying technology can be held liable for contributory infringement if the technology is only theoretically capable of noninfringing uses, or if it is only rarely used for noninfringing purposes. Sony left the meaning of "capable" altogether up for grabs. So, too, it left unsettled the meaning of the crucial terms "commercially significant"109 and "substantial."110 How commercially significant, how substantial, must the noninfringing uses of a copying technology be for a distributor with "clean hands" to be immune under Sony? These questions were engaged by the concurring opinions, but they were left entirely unanswered by the Court's unanimous opinion, an outcome that is somewhat frustrating for those of us who had hoped for a more definitive application of Sony. The breakdown of the Court appears to be three-three, with three

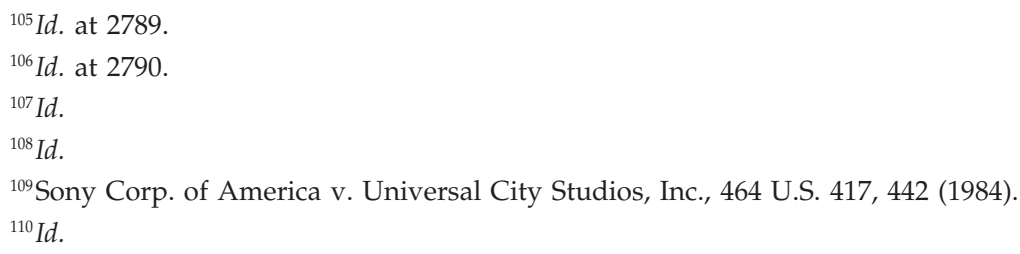


abstentions, on the "nice question" of whether the Grokster and StreamCast software programs, considered apart from their distributors' culpable acts of inducement, come within the protective limits of Sony's safe harbor. Rather than treating the Grokster case as an occasion to define the contours of Sony more tangibly in the context of Internet file sharing, the Court, as it turned out, rewound to Sony, but it never hit "play." 
